\title{
NUTRIENT COMPOSITION, AVAILABILITY, CURRENT AND POTENTIAL USES OF DUSA: A CEREAL BY-PRODUCT OBTAINED FROM “KOKO" (PORRIDGE) PRODUCTION
}

\author{
D.B. Okai, P.K. B. Abora, T. Davis, and A. Martin, \\ Department of Animal Science, Faculty of Agriculture, \\ College of Agriculture and Natural Resources, \\ Kwame Nkrumah University of Science and Technology, Kumasi.
}

\section{ABSTRACT}

Samples of Dusa, a cereal by-product derived from "Koko" (porridge) production, from twenty "Koko" producers located at Aboabo, Akwatia Line, Dagomba Line, Adukrom, Roman Hill and Sabon-Zongo, all suburbs of Kumasi in the Ashanti Region of Ghana were analysed to determine nutrient composition, establish the extent of availability, the current and potential uses. Questionnaires were administered at each production site to determine, inter alia, the type of cereals used, production processes, the extraction rate and cost $(\$ / \mathrm{kg})$ of dry Dusa. The samples were analysed for their proximate composition and (\%) NDF, ADF and Hemicellulose. The mean DM, CP, EE, $C F$, Ash and NFE ranged between 89.58-93.02, 10.51-21.86, 1.42-5.38, 4.70-10.77, 0.68-4.55 and $58.29-68.89 \%$ respectively and the corresponding mean NDF, ADF and Hemicellulose ranged from 27.56-62.47, 6.52-14.95 and 18.76-50.08\%. There were significant $(p<0.05)$ differences between the products from the different sites with respect to their $D M, C P, C F$, Ash and NFE contents. The survey showed that mainly backyard farmers patronised Dusa and the data collected indicated that the extraction rate for Dusa was $9.02 \%$. The price of dry Dusa ranged between 200.00 and $\$ 300.00 / \mathrm{kg}$. Dusa is comparable to other cereal by-products such as rice bran, maize bran, wheat bran, etc. in nutrient composition and can therefore be used in ration formulation for both ruminant and non-ruminant livestock.

Keywords: "Koko", "Dusa" Nutrient Composition, Uses,

\section{INTRODUCTION}

The diet of the average Ghanaian is low in animal proteins because of the low-income status and the high prices of most meat and meat products. Ghanaian poultry and livestock producers should therefore aim at supplying consumers with reasonably priced meat and meat products. The generally high cost of feed inputs has not made it possible for this goal to be achieved. This situation is partly the result of competition between man and livestock for some feed and food ingredients, particularly energy sources such as maize (Okai and Aboagye, 1990). The solution to this problem of escalations in prices of animal products may be in the use of alternative feed resources that are not competed for by man and are therefore cheaper. (Okai and Aboagye, 1990).

Agro-industrial by-products have been cvaluated in Ghana as potential alternative feed sources for the non-ruminant farm animals (Okai, 1998). Studies have involved wet brewers spent grains (Okai, et al, 1985) cocoa pod husk (Okai et al, 
1984), dried coffee pulp (Okai and Dabo, 1991), mango kernel mcal (Okai and Aboagye, 1986), oil palm slurry (Abu et al, 1984), among others.

Dusa is a by-product obtained from the production of "Koko" (porridge) from maize and/or millet. "Koko", a common breakfast meal in Ghana is made from partially fermented cereal flour, with or without spices (like ginger, pepper, etc.). Dusa, the solid mass left after sieving/ straining the dough or flour in water can serve as good feed resource for feeding family-owned domestic animals. Preliminary studies by the authors showed that in most cases, Dusa is not used but rather thrown away or left to spoil. This may be due 10 the fact that there is dearth of information on its nutrient composition and production Icvels.

The objectives of this study therefore were to find out the extent of availability of Dusa in the Kumasi area, determine the nutrient composition of Dusa from various production processes and provide information on the current uses of Dusa.

\section{MATERIALS AND METHODS}

\section{Dusa Collection and Handling}

Samples of Dusa, each of about $1.0 \mathrm{~kg}$ wcight were collected from twenty (20) different "koko" producers located at Aboabo, Akwatia Line, Dagomba Line, Roman Hill, Adukrom and Sabon-Zongo, all suburbs of Kumasi. A questionnaire was prepared and administered to determine the type(s) of cereal used, the production processes, the extraction rate and cost (per kg) of dry Dusa. The samples were dried in a tunnel solar dryer at a temperature of $50^{\circ} \mathrm{C}$ for three days. The dried samples were milled in a blender, packed in airtight polythene bags and stored at room temperature.

\section{Chemical Analyses}

The dry matter (DM), crude protein (CP), ether extract (EE), crude fibre (CF) and ash contents were determined according to the procedures of the Association of Official Analytical Chemists (AOAC, 1990). Nitrogen- free- extract (NFE) levels were obtained by difference. The acid detergent (ADF), and neutral detergent (NDF) fibre contents of the samples were determined according to the procedures of Goering and Van Soest (1970). The hemicellulose levels were obtained as the difference between NDF and ADF.

\section{Extraction Rate}

The Extraction Rate (ER) of Dusa was cstimated as:

\section{Statistical Analyses}

The SPSS (1997) Inc. Version 8.0 was used to statistically analyse the data at the $0.05(5 \%)$ significance level.

\section{RESULTS AND DISCUSSION}

\section{Survey Data}

The distribution of the 20 koko producers in the suburbs of Kumasi is shown in Table I. Two (10\%) producers were located at Roman Hill while four $(20 \%)$ were from Akwatia line. The percentage of producers from Dagomba line was $20 \%$ while six (30\%) were from Aboabo; with $15 \%$ (i.e. 3 producers) coming from Sabon-
Zongo. There was only one (5\%) producer from Adukrom. The ages of the producers/sellers ranged from 16 to 65 with a mean of 37 years (Table I).

It was observed that $75 \%$ of the producers used millet, $10 \%$ used maize and $15 \%$ used maizemillct ratios of $1: 2,1: 3$ or $2: 1$ for "Koko" production (Table 1). All producers obtained these cereals from the open market. Initially seventyfive percent of the producers used between 1$10 \mathrm{~kg}$ of cereals daily while $20 \%$ were using 11 $20 \mathrm{~kg}$ of cereals/day and only $5 \%$ used more than 


\section{Table 1 Survey Data-Summary}

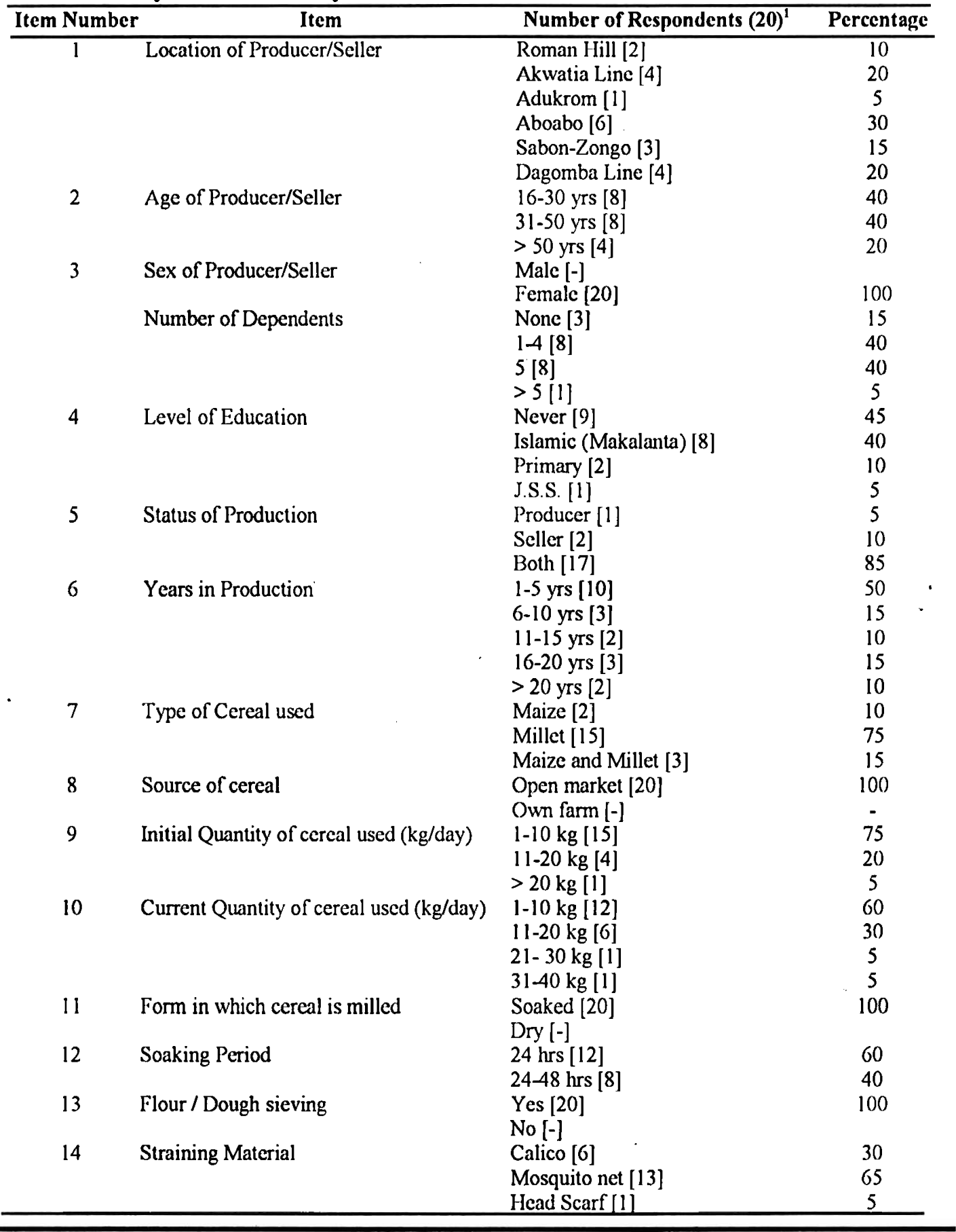




\begin{tabular}{cllc}
\hline Ilem Number & Item & Number of Respondents (20)' & Percentage \\
\hline 15 & Use of Dusa & Fed to Animals [7] & 35 \\
& & Thrown away [5] & 25 \\
& & Sold [7] & 35 \\
16 & Animals fed to & Given away [1] & 5 \\
& & Sheep [4] & 57.1 \\
& & Sheep and Goats [1] & 14.3 \\
17 & Form fed to Animals & Sheep and Cattle [1] & 14.3 \\
& & Sheep and poultry [1] & 14.3 \\
18 & Why thrown away & Dry [4] & 57.1 \\
& & Wet [3] & 42.9 \\
19 & Form in which Dusa is sold & Of no known use [3] & 60 \\
& & Difficult to dry [2] & 40 \\
20 & Price of dry Dusa & Dry [6] & 85.7 \\
\end{tabular}

'Figures in parenthesis represent number of respondents for a particular category

Table 2: Proximate Composition of Dusa from Twenty Producers. (\%, air- dry)

\begin{tabular}{|c|c|c|c|c|c|c|c|}
\hline SAMPLE & DUSA-TYPE & $\mathrm{DM}$ & $\mathrm{CP}$ & $\mathrm{EE}$ & ASH & $\mathrm{CF}$ & NFE \\
\hline 1 & Millet & $91.98^{6 c}$ & $13.92^{\circ}$ & $2.11^{\mathrm{d}}$ & $1.26^{1}$ & $6.66^{1}$ & $68.04^{26}$ \\
\hline 2 & " & $90.15^{d e}$ & $12.89^{\circ}$ & $2.48^{d}$ & $1.50^{\mathrm{ef}}$ & $10.78^{2}$ & $62.53^{\circ}$ \\
\hline 3 & ", & $90.45^{d}$ & $12.84^{\text {ef }}$ & $2.50^{\mathrm{d}}$ & $1.87^{\star}$ & $8.69^{c}$ & $64.54^{d}$ \\
\hline 4 & $\because$, & $92.38^{2}$ & $15.02^{\mathrm{c}}$ & $3.74^{b x}$ & $1.89^{d}$ & $9.31^{b}$ & $62.42^{\circ}$ \\
\hline 5 & Maize & $90.31^{d}$ & $11.55^{8}$ & $3.24^{c}$ & $0.98^{\mathrm{B}}$ & $8.82^{c}$ & $65.71^{c .}$ \\
\hline 6 & Maize & $91.24^{\mathrm{c}}$ & $14.31^{d}$ & $4.19^{b}$ & $0.69^{h}$ & $7.69^{e}$ & $64.36^{d}$ \\
\hline 7 & Millet & $93.02^{1}$ & $12.66^{f f}$ & $4.17^{b}$ & $2.59^{\mathrm{C}}$ & $6.44^{f}$ & $67.17^{b}$ \\
\hline 8 & $\mathrm{M}+\mathrm{M}^{1}$ & $90.18^{d k}$ & $14.86^{\text {dd }}$ & $5.38^{\prime}$ & $3.72^{b}$ & $7.92^{\mathrm{e}}$ & $58.29^{8}$ \\
\hline 9 & $M+M$ & $89.91^{d k}$ & $14.30^{d}$ & $1.42^{\circ}$ & $0.85^{\text {gt }}$ & $4.70^{h}$ & $68.49^{\circ}$ \\
\hline 10 & Millet & $91.45^{\mathrm{c}}$ & $13.94^{d}$ & $1.98^{\star}$ & $3.95^{b}$ & $5.50^{\mathrm{B}}$ & $66.08^{b c}$ \\
\hline 11 & “ & $89.96^{d e}$ & $11.22^{\mathrm{B}}$ & $4.15^{\circ}$ & $1.68^{\circ}$ & $7.69^{\circ}$ & $64.97^{\mathrm{cd}}$ \\
\hline 12 & . & $89.82^{d k}$ & $13.02^{\circ}$ & $1.43^{\circ}$ & $1.62^{\mathrm{ef}}$ & $9.19^{\mathrm{bc}}$ & $64.56^{d}$ \\
\hline 13 & " & $89.58^{e}$ & $14.68^{\circ}$ & $3.72^{*}$ & $1.45 \mathrm{ef}$ & $8.93^{c}$ & $60.80^{r}$ \\
\hline 14 & “ & $89.59^{\circ}$ & $17.11^{6}$ & $3.31^{\mathrm{c}}$ & $1.38^{f}$ & $7.69^{\circ}$ & $60.11^{f}$ \\
\hline 15 & $“$ & $90.98^{\mathrm{ed}}$ & $10.5 I^{b}$ & $2.01^{\star}$ & $1.64^{\mathrm{ef}}$ & $7.92^{e}$ & $68.89^{2}$ \\
\hline 16 & $"$ & $89.97^{\mathrm{de}}$ & $12.27^{r}$ & $3.85^{x}$ & $2.34^{c}$ & $5.81^{B}$ & $65.69^{c}$ \\
\hline 17 & « & $91.20^{c}$ & $13.06^{\circ}$ & $3.91^{b c}$ & $2.39^{c}$ & $6.36^{r}$ & $65.49^{\mathrm{cd}}$ \\
\hline 18 & “ & $90.85^{\text {ed }}$ & $21.86^{\circ}$ & $2.64^{d}$ & $2.01 \mathrm{~d}$ & $5.75^{B}$ & $58.59^{8}$ \\
\hline 19 & Millet & $90.97^{\text {ed }}$ & $13.78^{d}$ & $1.98^{\star}$ & $1.66^{\mathrm{e}}$ & $9.01^{\mathrm{bc}}$ & $64.54^{d}$ \\
\hline 20 & $\mathrm{M}+\mathrm{M}$ & $21.94^{b c}$ & $15.41^{e}$ & $3.96^{b e}$ & $4.56^{2}$ & $8.32^{d}$ & $59.69^{18}$ \\
\hline Mean & & 90.79 & 13.96 & 3.11 & 2.00 & 7.66 & 64.05 \\
\hline Std. Error & & 0.3000 & 0.2950 & 0.3140 & 0.1320 & 0.1620 & 0.5410 \\
\hline
\end{tabular}

$a, b, c, d, e, f, g, h$ Values in the same column with different superscripts are significantly $(p<0.05)$ different.

' $\mathrm{M}+\mathrm{M}$ - refers to the Maize+Millet mixture 
Table 3: Van Soest's Fibre Analyses of Dusa from Twenty Producers. (\% aịr-dry)

\begin{tabular}{|c|c|c|c|c|}
\hline SAMPLE & DUSA-TYPE & $A D F$ & NDF & HEMICELLULOSE \\
\hline & Millet & $9.44^{8}$ & $42.77^{k}$ & $33.33^{g h}$ \\
\hline 2 & & $14.94^{\circ}$ & $52.78^{\circ}$ & $3783^{\circ}$ \\
\hline 3 & & $10.73^{f}$ & $42.86^{k}$ & $32.13^{\mathrm{hi}}$ \\
\hline 4 & & $11.65^{\circ}$ & $62.48^{\circ}$ & $50.83^{2}$ \\
\hline 5 & Maize & $10.76^{1}$ & $29.52^{p}$ & $18.76^{\mathrm{m}}$ \\
\hline 6 & Maize & $10.19^{4}$ & $39.58^{1}$ & $29.38^{j}$ \\
\hline 7 & Miflet & $9.19^{8}$ & $44.69^{1}$ & $35.51^{1}$ \\
\hline 8 & $\mathrm{M}+\mathrm{M}^{1}$ & $12.70^{d}$ & $32.49^{\circ}$ & $19.79^{\mathrm{i}}$ \\
\hline 9 & $\mathrm{M}+\mathrm{M}$ & $6.52^{\mathrm{i}}$ & $38.43^{\mathrm{m}}$ & $31.91^{\mathrm{i}}$ \\
\hline 10 & Millet & $6.52^{i}$ & $51.29^{f}$ & $44.76^{\mathrm{c}}$ \\
\hline 11 & & $11.51^{\mathrm{ef}}$ & $47.03^{h}$ & $35.52^{f}$ \\
\hline 12 & & $13.22^{\mathrm{cd}}$ & $59.12^{b}$ & $45.95^{\mathrm{b}}$ \\
\hline 13 & & $13.36^{\mathrm{c}}$ & $54.87^{\circ}$ & $41.52^{d}$ \\
\hline 14 & & $10.93^{f}$ & $48.78^{8}$ & $37.83^{\mathrm{e}}$ \\
\hline 15 & & $12.43^{\mathrm{d}}$ & $53.86^{\mathrm{d}}$ & $41.43^{d}$ \\
\hline 16 & & $7.51^{i}$ & $27.57^{9}$ & $20.06^{1}$ \\
\hline 17 & & $8.21^{\mathrm{h}}$ & $40.21^{1}$ & $32.00^{\mathrm{i}}$ \\
\hline 18 & & $11.32^{\mathrm{e}}$ & $43.85^{j}$ & $34.07^{8}$ \\
\hline 19 & Millet & $10.92^{f}$ & $45.39^{i}$ & $32.93^{\mathrm{h}}$ \\
\hline 20 & $\mathrm{M}+\mathrm{M}$ & $14.10^{\mathrm{b}}$ & $37.63^{n}$ & $23.53^{k}$ \\
\hline MEAN & & 10.81 & 44.76 & 33.95 \\
\hline Std. Error & 0.287 & 0.2870 & 0.3350 & 0.4340 \\
\hline
\end{tabular}

$a, b, c, \ldots$. - Values in the same column with different superscripts are significantly $(p<0.05)$ different.

' $M+M$ : refers to Maize+Millet mixture.

$20 \mathrm{~kg}$ of cereals/day. At the time of the survey, $60 \%$ used $1-10 \mathrm{~kg}$ of cereals per day while $30 \%$ and $5 \%$ used $11-20 \mathrm{~kg}$ and $31-40 \mathrm{~kg}$ of cereals/ day respectively. The net weight of wet Dusa obtained per $\mathrm{kg}$ of cereal used ranged from 0.13 to $0.62 \mathrm{~kg}$ with a mean weight of $0.32 \mathrm{~kg}$ and the dry weight obtained per $\mathrm{kg}$ of cereals used ranged from 0.03 to $0.19 \mathrm{~kg}$.

The survey showed that $30 \%$ of the producers fed the Dusa to their ruminants and poultry while $25 \%$ ( 5 producers) threw the Dusa away claiming that they had no use for it. Another $35 \%$ of producers (7) sold the Dusa while the remaining $5 \%$ ( 2 producers) gave the Dusa to relatives and friends, who most probably fed this to their livestock. Among those who fed the Dusa directly to their animals, $57.1 \%$ fed it to only sheep, $14.3 \%$ fed it to both sheep and goats while another $14.3 \%$ fed it to both sheep and poultry. More than $50 \%$ of those who fed the Dusa to their animals used the dry form of the product (Table 1). The study showed that a vast majority ( $85.7 \%$ ) of those who sold Dusa, only sold the dry form and at an average price of $200 / \mathrm{kg}$. 
Table 4: Extraction Rate for Dusa

\begin{tabular}{|c|c|c|c|c|}
\hline Sample No. & Dusa Type & $\begin{array}{l}\text { Quantity of Grains } \\
\text { used (kg) (a) }\end{array}$ & $\begin{array}{l}\text { By-Product Ob- } \\
\text { tained (kg) (b) }\end{array}$ & $\begin{array}{c}\text { Extraction Rate (\%) } \\
\text { b/a } \times 100\end{array}$ \\
\hline 1 & Millet & 10.8 & 0.36 & 3.33 \\
\hline 2 & $\because *$ & 32.4 & 3.95 & 12.20 \\
\hline 3 & $\because$ & 16.2 & 1.88 & 11.60 \\
\hline 4 & $“$ & 5.4 & 0.36 & 6.67 \\
\hline 5 & Maize & 37.5 & 2.02 & 5.40 \\
\hline 6 & Maize & 15.0 & 1.23 & 8.24 \\
\hline 7 & Millet & 21.6 & 2.59 & 11.99 \\
\hline 8 & $M+M^{\prime}$ & 10.6 & 0.72 & 6.92 \\
\hline 9 & $M+M$ & 15.4 & 0.95 & 6.16 \\
\hline 10 & Millet & 10.8 & 0.79 & 7.31 \\
\hline 11 & “ & 13.5 & 2.49 & 18.40 \\
\hline 12 & “" & 8.1 & 0.59 & 7.28 \\
\hline 13 & “ & 8.1 & 0.90 & 11.11 \\
\hline 14 & $"$ & 8.1 & 0.78 & 9.63 \\
\hline 15 & " & 13.5 & 0.90 & 6.67 \\
\hline 16 & " & 8.1 & 0.46 & 5.68 \\
\hline 17 & $"$ & 8.9 & 1.41 & 7.46 \\
\hline 18 & “ & 13.5 & 1.09 & 8.07 \\
\hline 19 & Millet & 8.1 & 0.51 & 6.29 \\
\hline 20 & $\mathrm{M}+\mathrm{M}$ & 10.2 & 0.87 & 8.52 \\
\hline Mean & & 13.51 & 1.24 & 9.02 \\
\hline
\end{tabular}

${ }^{\prime} M+M-$ refers to Maize + Millet mixture 
NUTRIENT COMPOSITION OF DUSA

Dry Matter (DM)

As shown in Table 2, the DM in the dry Dusa ranged from 89.58 to $93.02 \%$. The mean valuc for the millet-lypc Dusa samples was $90.82 \%$. The maize-type Dusa had a mean value of $90.78 \%$ whilc the maize+millet Dusa had a mean value of $90.35 \%$. Significant differences $(\mathrm{P}<0.05)$ in DM were observed and this could be attributed to the different soaking periods for the cereals. Other factors that were considered to contribute to the differences in the DM were the pressure cxerted at sicving, the age and cxperience of the producer logether with the sicve material. For example Dusa obtained from the use of the "mosquito" net as the sicve had higher DM than that from calico.

\section{Crude Protein (CP)}

The CP level of the Dusa samples was quitc variable and ranged from 10.5 to $21.86 \%$ (Table 2). The millet-type Dusa samples had a mean CP value of $13.93 \%$ and ranged between 10.5 land $21.86 \%$. On the other hand, the maize-type samples had values of $11.55 \%$ and $14.31 \%$ with a mean $\mathrm{CP}$ value of $12.93 \%$. The mean $\mathrm{CP}$ content of the maize + millet type Dusa was $14.85 \%$ and the values for the 3 samples in this category were $14.30,14.86$ and $15.42 \%$. Sample 18 (a millet- typc Dusa) was significantly $(\mathrm{p}<0.05)$ higher in CP than all the other samples. The very high CP value (21.86\%) of the millet-type Dusa labelled sample 18, was unexpected but could be attributed to varietal difference in the millet grains. The range of $\mathrm{CP}$ values obtained from the millet samples in this study may be considcred consistent for the grain (Deyoe and Robinson, 1979; Kent, 1980). The maize-type samples had significantly $(P<0.05)$ lower $C P$ than the millet-type due to the differences in protein content of these two cereals. Maize has an average CP of $9.0 \%$ compared to $14.4 \%$ for millet (Gohl, 1981). The levels of nutrients in the soil particularly nitrogen might influence the level (s) of a particular nutrient in the crop grown on that soil. . Hulse et al. (1980) indicated that several workers particularly those working on poor tropical soils had obtained increases in grain yicld and grain protcin content in pearl, finger and common millets with the addition of fertilizers. They further stated that the protein content of sorghum grains incrcascd from 8.4 to $9.5 \%$ as $\mathrm{N}_{2}$ application lcvels increased from $0-200 \mathrm{kgN} /$ ha. The production processes of soaking and wet milling during "Koko" production might also contribute towards difference in $\mathrm{CP}$ content of the by-product.

\section{Crude Fibre (CF)}

The millet-type Dusa samples had an average CF valuc of $7.72 \%$ with range of 4.70 10 $10.78 \%$, while the maize-type Dusa had a range of 7.69 to $8.82 \%$ CF with an average of $8.26 \%$. The mixture (i.c. maize + millet) type Dusa had a range of 4.70 to $8.32 \%$ with a mean value of $6.98 \%$. There were significant differences $(\mathrm{p}<0.05)$ between the CF values of the Dusa samples. The different levels of spices added to the grains before milling might have contributed to the differences in the $C F$ values. Ginger, which is commonly used as a spice is quite fibrous and could influence the overall $\mathrm{CF}$ profile of the end product. These significant differences could also be attributed to the differing fibre levcls in the two raw materials used in "koko" production and also to varictal $C F$ differences of any particular cercal. It should however bc noted, that the varictics of the cercals used in "koko" production were not determined in this study.

Gohl (1981) reported different CF levels for millet grains of different varietics from different arcas. He reported $1.5 \%$ for bulrush millet from Ghana, $5.9 \% \mathrm{CF}$ for finger millet from Zimbabwe and $10.0 \%$ CF for foxtail millet from the U.S.A. McDonald et al. (1995) reported that some of the hulls in millet were not removed by the normal harvesting methods. This could $\mathrm{cx}-$ plain the higher $\mathrm{CF}(10.78 \%)$ level in millet-typc Dusa (Sample 2). Dusa could be used for feeding pigs as they can utilise efficiently diets with 7\% CF level (Vleck, 1970). 


\section{Ash}

The mean ash content in the Dusa samples was 2.00. The millet-type Dusa samples had a mean ash value of 1.92 , the maize-type Dusa samples had a mean ash value of 0.82 and the mixturetype Dusa had a mean ash value of 2.71 . The maize-type Dusa had a significantly $(\mathrm{p}<0.05)$ lower ash content than the other samples. The levels of minerals in the cercals could depend on such factors as variety, soil condition, temperature, rainfall and fertilizer application (Deyoe and Robinson, 1979).

\section{Ether Extract}

The millet-type Dusa samples had a mean EE level of $2.93 \%$ while the maize-type Dusa samples had a mean of $3.72 \%$ with the maize+millet type Dusa samples having a mean value of $3.4 \%$. The EE values were significantly $(\mathrm{p}<0.05)$ different. The millet-type Dusa samples, 1, 2, 3, $10,15,18$ and 19 were similar $(\mathrm{p}>0.05)$ in EE content. Samples 4, 6, 7, 11, 13,16 and 17, and 20 were also not significantly ( $p>0.05$ ) different. However, Sample 8, which was a mixture-type Dusa had significantly $(\mathrm{p}<0.05)$ higher EE content than the rest of the samples. The differences in the \% EE values for the maize + millet samples may be attributable to the different fat contents of the different cereal grains used. The variations in the \% $\mathrm{EE}$ values for maize or millet only Dusa can be due to the type of cereal and its nutrient composition. Gohl (1981) indicated that the EE content for bulnush millet from Ghana and finger millet from Zimbabwe were 5.2 and 3.6 respectively while Southgate (1993) gave a range of $2-7 \%$ for most cereals.

\section{Nitrogen Free Extract (NFE)}

The millet-type samples had a mean NFE value of $59.94 \%$ while that for the maize-type Dusa was $64.05 \%$. The mixture-type Dusa samples had a mean NFE value of $63.4 \%$. Samples land 15 (millet-type Dusa samples) had significantly $(p<0.05)$ higher values than the other samples (Table II). The mean NFE of the Dusa studied here was $64.05 \%$. Locally-produced rice bran and maize bran may have as much as 50 $80 \% \mathrm{NFE}$ and rice bran from Philippincs and Iraq had 46.1 and $46.3 \% \mathrm{NFE}$ respectively while wheat bran from Tanzania had $61.6 \%$ NFE (Gohl, 1981). Dusa would therefore be expected to have similar or better feeding value for poultry and livestock.

\section{Detergent Fibre (DF) Analysis}

The mean NDF value for Dusa was $44.76 \%$ (Table 3). While the millet-type Dusa samples had a mean value of $47.83 \%$, the maize-typc Dusa samples had a value of $34.58 \%$. The mixture-type Dusa samples, on the other hand, had a vlue of $35.46 \%$ and the differences between these means were significant $(P<0.05)$. Generally, the millet-type Dusa samples had significantly $(p<0.05)$ higher NDF values than the maize and the mixture-type Dusa samples. This may as stated earlier, be attributed to the presence of more hulls in the millet-typc Dusa (McDonald et al., 1995).

The mean ADF value for the Dusa samples was $10.81 \%$. Thete was a wider range of values for the millet-type Dusa samples (6.52 to $14.95 \%$ ) than for the maize-type Dusa samples (i.e. 10.76 and $10.19 \%$ ). The mixture samples had a mean $A D F$ value of $10.31 \%$ and the means were significantly $(\mathrm{P}<0.05)$ different. Gencrally, the $A D F$ values were higher than the $C F$ values (Tables II and III) because the ADF fraction contains lignin in addition to cellulose (Mertens, 1985).

The mean hemicellulose value of the Dusa samples was $33.95 \%$; while the millet-type Dusa samples had a mean value of $40.5 \%$, the maizetype Dusa samples had a value of $24.1 \%$. The mixture-type Dusa samples had a value of $21.7 \%$. This affirms that there can be considerable differences in the nutrient profiles of feed and food ingredients. 


\section{THE EXTENT OF AVAILABILITY OF} DUSA

The mean extraction rate for all the Dusa samples was $9.02 \%$ (Table 4). The mean rate for the maize-type Dusa samples was $6.2 \%$. The maize+millet Dusa samples had a mean extraction rate of $7.4 \%$. Interestingly the highest and the lowest rates of 18.40 and $3.33 \%$ were obtained from the millet-type Dusa samples but generally, the millet-type Dusa samples had higher extraction rates than the maize and the mixture-type Dusa samples. This may probably be due to the relatively higher levels of hulls in the millet grains.

The annual production of maize and millet is about 1,182,000 metric tonnes (MOFA, 2001). If it is assumed that at least 100,000 metric tonnes of these cereals are used for "koko" production then it means that about 9,020 tonnes of Dusa can be produced annually for feeding livestock and poultry. Dusa was being sold at $\$ 200-300 /$ $\mathrm{kg}$ dry weight at the time of study and a $16-25 \mathrm{~kg}$ bag was priced at approximately $₫ 5,000$, on the other hand, a $25 \mathrm{~kg}$ bag of wheat bran was being sold at $₫ 16,000$ at the time of the study. This suggests that livestock and poultry producers could reduce the cost of feeding their animals by making more extensive use of Dusa.

\section{CONCLUSION}

This study has shown that the nutrient composition of Dusa could be variable. The millet-type Dusa had higher CP than the maize and the mixture-types. Some "koko" producers used Dusa partly in feeding their domestic animals. Somc backyard poultry/pig farmers do buy or collect Dusa. It was estimated that about 9,020 metric tonnes of Dusa could be available for feeding livestock and poultry annually.

Dusa could help to further reduce the production cost of meat and meat products thereby making them more affordable. However, the problem of how to dry it quickly and efficiently especially in the very humid areas of Ghana would need to be addressed.

\section{ACKNOWLEDGEMENT}

The active support reccived from the Head and staff of the Department of Animal Science, KNUST is gratefully acknowledged. The authors are highly appreciative of the contributions of Messrs E. Nyannor and Michael Boateng and Ms. Irene Tandoh, all of the Department of Animal Science.

\section{REFERENCES}

Abu, A., Okai, D. B. and Tuah, A. K. (1984). Oil palm slurry as a partial replacement for maizc in the diets of growing-finishing pigs. Nutr. Rep. Int. 30: 121-128.

AOAC (1990). Association of Official Analytical Chemists. Official Methods of Analysis, $15^{\text {th }}$ Edn. Arlington, Va., USA.

Deyoc, C.W. and Robinson, R.G. (1979). Tropical Foods: Chemistry and Nutrition. Proceedings of an International Conference on Tropical Foods. 1: 217-233

Goering, H.K and Van Soest, P.J. (1970). Forage Fibre Analyses (Apparatus, Reagents, Procedures and Some Application). ARS, U.S. Dept. Agr. Handbook, No. 379, Supcrintendent of Documents, USA.

Gohl, B (1981). Tropical Fecds: Fced Information Summaries and Nutritive Values. FAO, Animal Production and Health Series No. 12. Rome, Italy.

Hulse, J.H., Laing, E. M. and Pearson, O..E. (1980). Sorghum and Millets: their Composition and Nutritive Value. Academic Press, A Subsidiary of Harcourt Bruce Jovanovich Pub-/ lishers, Ottawa, Canada.

Kent, N.L. (1980). Technology of Cereals with Special Reference to Wheat. $2^{\text {nd }}$ Edn. Pergamon Press, Oxford. 
McDonald, P.M., Edwards, R.A., Greenhalgh, J. F.D. and Morgan, C.A. (1995). Animal Nutrition. $5^{\text {th }}$ Edn. Addison Wesley Longman, Singapore Pte. Lid.

Mertens, D.R. (1985). Recent Concept Useful in Optimizing Nutrition of Dairy Cows. Proc. Minnesota Nutr. Conf. Minnesota.

Ministry of Food and Agriculture (MOFA, 2001). Agriculture in Ghana. Facts and Figures. Issued by Statistics, Research and Information Directorate, MOFA, Accra.

Okai, D. B (1998). Alternative Feed Resources for Pigs in Ghana. DeGraft Graphics and Publication, Kumasi.

Okai, D.B. and Aboagye, J. (1986). Mango Kernel Meal (MKM) as a feed ingredient - effects on the performance of weanling rats. Proc. 14$17^{\text {th }}$ GASA. Symp. KNUST, Kumasi p. 64 (Abstr.)

Okai, D.B. and Aboagye, J. (1990). The effects of mango seed kernel meal (MSKM) on the performance of growing rat, Biol. Wastes 34: $171-175$

Okai, D.B. and Dabo, P. (1991). Further studies on the effects of diets containing dried coffee pulp (DCP): growth performance, blood and carcass characteristics of pigs. J. Trop. Agric. \& Vet. Sci., 2:235-241

Okai, D.B., Lamptey, E. L. and Kwarteng, F. A. (1985). Wet brewers' spent grains (WBSG) in the diets of finishing pigs. Proc. 14-1 $17^{\text {th }}$ GASA Symp. Univ, of Ghana, Lcgon. Pp. 8793

Okai, D.B., Osafo, E. L. K. and Adomako, D. (1984). Effects of different levels of cocoa pod husk on the performance and carcass characteristics of finisher pigs. Proc. $9^{\text {th }}$ Int. Cocoa Res. Conf., Lome, Togo. Pp. 455-459

Southgate, D.A.T. (1993). Nutrients in Food. Human Nutrition and Dietetics. Garrow J.S. and James W.P.T. (Ed) $9^{\text {th }}$ Edn. Churchill Livingstone Publication, USA.

SPSS (1997). Inc. Version 8.0. Statistical Program for Social Scientists, UK.

Vleck, A. (1970). Influence of the amount of crude fibre on the digestibility of fecds of pigs. Nutr. Abstr. Rev. 40 (3), No. 6319. 